\title{
AWARENESS, PERCEPTIONS AND WILLINGNESS TO PAY FOR PRO VITAMIN A GARRI: EVIDENCE FROM IDO LOCAL GOVERNMENT OF OYO STATE, NIGERIA
}

\author{
Omotoso Oluseye Ogunmola ${ }^{\natural}$, Adeleke Adeyinka Adekanmbi ${ }^{2}$ \\ ${ }^{1}$ Bowen University Iwo, Osun State, Nigeria \\ ${ }^{2}$ Federal University of Agriculture Abeokuta, Ogun State, Nigeria
}

\begin{abstract}
Efforts made to combat vitamin A deficiency are a crucial feat for public health services dealing with vulnerable people in developing nations. Therefore, this study examined the awareness, perceptions and willingness to pay for pro-vitamin-A garri in Oyo state, Nigeria. A multistage sampling procedure was used to collect data from 150 sampled respondents. Data was analyzed using descriptive statistics and the double-hurdle model. The results revealed that while ca. $47.5 \%$ of the respondents are aware of the availability of pro-vitamin-A garri, the levels of awareness are low. However, $67.3 \%$ of the consumers are aware of pro-vitaminA garri thanks to agricultural extension agents, radio and friends. The maximum, minimum and average amount the consumers were willing to pay per kilogram of pro-vitaminA garri was NGN 500 (USD 1.39), NGN 160 (USD 0.44) and NGN 220.08 (USD 0.61), respectively. The double-hurdle model showed that income, other income streams and awareness exerted a significant and positive influence on the consumers' willingness to pay for pro-vitamin-A garri. Similarly, education and radio-induced awareness significantly and positively influenced the amount they were willing to pay per kilogram of pro-vitamin-A garri. Conversely, household size had a significant negative influence. The study advocates for nutrition education as an important tool in communicating the nutritional and health benefits of bio-fortified crops.
\end{abstract}

Keywords: awareness, perception, pro-vitamin-A garri, willingness to pay

\section{INTRODUCTION}

Cassava is an important and the most widely consumed staple food in Nigeria. It is a starchy root tuber which contributes to the staple of millions worldwide, many of whom live in sub-Saharan Africa (SSA). Cassava originates from Latin America but was introduced to Africa by the Portuguese in the sixteenth century as a possibly useful crop (Akinpelu et al., 2011). It was reported that ca. 121 million tons of cassava are produced in Africa (Parkes et al., 2013). Globally, cassava production and consumption has substantially increased over the past few years with sub-Saharan Africa having the highest growth from 48.3 million tons in 1980 to 95.3 million tons in 2011 (Egesi et al., 2006; FAO, 2013). This growth is championed by Nigeria, the largest producer of cassava, followed by Ghana (FAO, 2013). Cassava is a very versatile commodity with numerous uses and by-products. The roots are processed for human and industrial consumption. Various products can be derived from cassava, including garri, cassava flour, wet pulp, starch, smoked cassava balls and dried cassava (Truman et al., 2004).

Root crops are predominantly white in color and do not contain pro-vitamin-A. Over the decade, there have been a series of interventions to improve human diets as a result of increasing incomes and administration

$\bowtie$ Omotoso Oluseye Ogunmola, Department of Agricultural Economics and Extension, Bowen University Iwo, Osun State,

Nigeria, e-mail: omotoso.ogunmola@bowen.edu.ng; https://orcid.org/0000-0001-6010-7123 
of vitamin-A capsules (Ilona et al., 2017; Egesi et al., 2006). The production of pro-vitamin-A cassava started in 2011 with the intervention of the International Center for Tropical Agriculture (CIAT) and the International Institute of Tropical Agriculture (IITA) funded by the HarvestPlus program. About five years after the intervention, statistics revealed that 1 million Nigerian farm households grow yellow cassava varieties which contain substantial quantities of pro-vitamin-A even after processing. In Nigeria diets, yellow cassava now represents an additional source of vitamin A (Saltzman et al., 2014). Human diets consist of two forms of vitamin A: preformed vitamin A (retinol) and pro-vitamin-A carotenoids. Preformed vitamin A is dominant in animalsourced foods; pro-vitamin-A is found in some vegetable foods, and is metabolized by the body into retinol when consumed (Green and Fascetti, 2016; Tanumihardjo et al., 2016). The Estimated Average Requirement (EAR) for vitamin A is $275 \mu \mathrm{g}$ retinol for children (between 4 and 6 years old), ca. $500 \mu \mathrm{g}$ retinol for women and $600 \mu \mathrm{g}$ retinol for men (Sanusi and Akinyele, 2006). Consumption of adequate quantities of vitamin $\mathrm{A}$ is imperative for sound and healthy immune functions (Sanusi and Akinyele, 2006; Katona and Katona-Apte, 2008). When deficient, it causes severe visual impairment and magnifies the risk of illness and death from common infections (Kennedy et al., 2003; FAO, et al., 2015; Kuku-Shittu et al., 2013; West and Darnton-Hill, 2008; West, 2002). Vitamin A is concentrated in relatively few foods (Meenakshi et al., 2010). Although the richest sources of preformed vitamin A in the Nigerian diet are animalbased (e.g. liver, dairy products, fish oils, and eggs), the most common sources of the nutrient are pro-vitaminA carotenoids, including beta-carotene derived from orange and yellow fruits and vegetables (pumpkin, yellow squash, carrots, yellow sweet potatoes, green leafy vegetables, mango, papaya, and other local carotene-rich fruits), some of which are highly seasonal in availability (Ender et al., 2014; Oparinde et al., 2016).

The recent national outcome on vitamin A deficiency (VAD) in 2001 showed that $29.5 \%$ of pre-school children and $13 \%$ of women of childbearing age are vitamin A deficient (Maziya-Dixon et al., 2006). However, there is no recent comprehensive national data on vitamin A deficiency (VAD) in Nigeria. In lieu of this, it could be concluded that Nigeria is not effectively monitoring vitamin A deficiency. Owing to periodic disparity in dietary intake and vitamin A deposits in the body, its inadequacy does not always result in clinical VAD. The most effective and vast instruments for checking VAD are diet revitalization via nutrition education, adequate and constant supply of mega-doses of vitamin A and fortification of staple foods with vitamin A (Ilona et al., 2017; Kuku-Shittu et al., 2013). Nigeria has adopted all of these options but not well enough to exert a quantitative impact on consumers. Vitamin A became wellknown after enacting laws requiring vitamin A fortification of all wheat flour, maize flour, edible vegetable oil, margarine and sugar (Sanusi and Akinyele, 2006; Uchendu et al., 2012; Ogunmoyela et al., 2013).

Cassava is a common staple food in Nigeria, and vitamin A cassava increases vitamin A intakes among its consumers. Since the varieties of cassava pulp normally consumed are white, an effective introduction of vitamin-A cassava (yellow cassava) will be contingent on its acceptability and consumption by the populace in Nigeria. In Nigeria, cassava is predominantly consumed as garri which means "free flowing creamy white or yellow granular partially gelatinized flour produced from cassava" (Cardoso et al., 2005). It is produced through the process of peeling, washing, grating, bagging and dehydration (with the aid of hydraulic press), fermentation, sieving, frying, cooling and packaging. Its longevity and ease of preparation (compared to other cassava food products) makes garri a widely consumed food (Sanni et al., 2008). Predilection for garri varies across ethnicity and regions of the country. The southeastern region consumes yellow garri, whereas most of the garri consumed in the southwest is white. However, garri can be possibly found in different shades of yellow in both regions (Oparinde et al., 2016). There are essential positive contributions of pro-vitamin-A garri in human diet: it provides up to $40 \%$ of vitamin $\mathrm{A}$; it is richer in betacarotene and a better source of energy than the local white garri; food like vitamin-A cassava moimoi fortified with beans and cassava custard is of good quality for children; pro-vitamin-A eba/garri (natural, without additional oil) has a good curling quality in lafun/eba (Talsma et al., 2016). A consumer acceptance study conducted in 2011 in two Nigerian states showed that vitamin-A cassava varieties, when supplied with nutrition information, were generally accepted and desired after an evaluation of their sensory features, form and texture. Also, the consumers' willingness to pay revealed the wide acceptability of vitamin-A cassava (Oparinde et al., 2016). However, if supplied without nutrition 
information and awareness, the results were different. Garri mixed with palm oil was preferred over that made from vitamin-A cassava in Imo State, while Oyo State consumers mainly preferred garri made from a lighter, colored vitamin-A cassava variety.

Vitamin A deficiency is a major public health challenge among the vulnerable niche of young people in developing nations (Greiner, 2017) where food-based policies are recommended as encouraging methods to meet vitamin A needs. It is therefore expedient to improve the nutritional content and flavor of garri, and to produce a unit product with standard and improved nutritional content. However, it is against this background that pro-Vitamin-A Garri (VAG) as a new product of pro-vitamin-A cassava has a great potential to alleviate Vitamin A Deficiency (VAD). Consumer awareness, perceptions and willingness to pay will help in disseminating pro-vitamin-A garri to complement current efforts made to address VAD by delivering vitamin A through a staple food consumed on an everyday basis. Also, this can be a complementary approach to other interventions. In view of the above, this paper investigates the awareness, perception, willingness to pay and the intensity of willingness to pay for pro-vitamin-A garri among rural consumers in Ido Local Government Area of Oyo State, Nigeria.

\section{THEORETICAL MOTIVATION AND CHOICE OF ECONOMETRIC MODEL}

The review of relevant literature explains the techniques of estimating the consumer's willingness to pay (WTP) for agricultural produce. The following three techniques exist: contingent valuation method; the revealed preference theory; and a combination of the use of theory along with microeconomic household variables and market variables (used to indirectly estimate the appropriate market premium). However, of among the preference methods listed above, the contingent valuation method is vastly recommended in situations where there is no or little market information, and has been widely adopted and used by many researchers (Vandeveer and Loehman, 1994; Sarris et al., 2006; Liu and Zhang, 2011; Nakanyike, 2014; Taneja et al., 2014; Okoffo et al., 2016; Oyawole et al., 2016; Adekunle et al., 2016). This is because it helps to motivate the concept of choice in a market situation as respondents have the opportunity to accept or reject the product. The significant importance of the contingent valuation method widens its usage in various agriculture-related studies to estimate the farmers' and consumers' willingness to pay for a service, product or technology. For instance, Ulimwengu and Sanyal (2011) adopted the method in analyzing the farmers' willingness to pay for agricultural services. Other use cases include studies by Kwadzo et al. (2013) and Danso-Abbeam et al. (2014). The contingent valuation method relies on surveys that are specifically designed to measure the preferences and willingness to pay (Taneja et al., 2014). Based on its importance, the contingent valuation was used in this study.

One of the major problems often encountered in empirical studies like this one is the absence of response. Therefore, the Ordinary Least Square regression is unsuitable for this analysis as the estimates will be biased. A number of econometric models have been proposed and used to handle the observed zeros (in the dependent variable) based on the assumptions made by the researcher about the potential sources of the observed zero responses. These are the Tobit, Heckman, double-hurdle and infrequency of purchase models. Various studies used either the double hurdle model or Heckman's sample selection model in determining the willingness to pay for agricultural goods and services (Cragg, 1971; Norris and Batie, 1987; Gabre-Madhin et al., 2003; Sindi, 2008; Wodjao, 2008; Yu and Abler, 2010; Musah, 2013; Khan and Damalas, 2015; Okoffo et al., 2016). The double-hurdle model was adopted in this study because of its advantage over the Heckman's sample selection model. The Heckman sample selection model assumes that no zero response will be present in the second hurdle of the analysis once the first hurdle is passed. The double hurdle, on the other hand, recognizes the possibility of zero observations in the second stage (Wodjao, 2008). A zero-response situation is possible because the consumer may refuse to answer due to lack of knowledge or to the perceived complexity of questions. In addition, some consumers may only have partial information on their willingness to pay for provitamin-A garri (Yu and Abler, 2010). For this scenario, it is possible that respondents cannot give a number representing their WTP but may recognize the fact that they have a positive WTP. Therefore, it is appropriate to use a double-hurdle model in which adoption behavior consists of two decisions: an adoption decision, i.e. a binary choice modeled using a logit; and a WTP amount decision, which is a truncated regression model (Cragg, 
1971). The double hurdle is used in a situation where an event may occur or not; and when it does, it takes on continuous positive values (Gabre-Madhin et al., 2003). It is assumed that the consumers are faced with hurdles in their decision-making process. Hence, the decision to pay is made first, followed by the decision on how much to pay for pro-vitamin-A garri. The two equations are assumed to be independent.

\section{METHODOLOGY}

\section{Study area}

This study was conducted in Ido Local Government Area of Oyo State, one of the six states in southwest Nigeria. One of the ancient states of the nation, it is well known for agricultural practices. Just like other local government units, Ido Local Government (with Ido as the capital city) was created in May 1989. It is located at latitudes between $7^{\circ} 45^{\prime} \mathrm{N}, 7^{\circ} 15 \mathrm{~N}$ and at longitudes between $3^{\circ} 30^{\prime} \mathrm{E}, 3^{\circ} 50^{\prime} \mathrm{E}$, and has a population of 103,261 and an area of $986 \mathrm{~km}^{2}$ (NPC, 2006). It has a relatively high humidity, with average daily temperatures ranging between $25^{\circ} \mathrm{C}\left(77^{\circ} \mathrm{F}\right)$ and $35^{\circ} \mathrm{C}\left(95^{\circ} \mathrm{F}\right)$ almost all year round (Weather2, 2017). The vegetation pattern consists of rainforest in the south and Guinea Savannah in the north. Ido enjoys abundant rainfall of over $1800 \mathrm{~mm}$ annually; south-westerly winds blow over the LGA during most of the year. The climate in the local government area favors the cultivation of crops like maize, yam, cassava, millet, rice, plantain, cocoa, oil palm and cashew (Denton and Ogunkunle, 2014). The study area is well known for the cultivation of crops and rearing of animals as the population's main occupation, the other being blacksmithing, carpentry, hairdressing, tailoring, trading etc. This area was chosen because Ido Local Government is predominantly known for cassava production.

\section{Sampling procedure and sample size}

Data for this study was collected from 150 respondents who were adult members of the houses interviewed in a cross-sectional survey using a structured questionnaire which served as the interview guide. The selection process involved three stages. First, Ido town was purposively selected out of every other town in the Local Government Area (LGA) because of high concentration of cassava production in the area. Then, five (5) towns were selected from the Local Government Area based on the simple random sampling procedure. Thereafter, thirty (30) buildings were randomly selected from each of the selected towns and an adult member (respondent) was selected in each building to make a total of 150 households. However, 30 questionnaires were not adequately filled by the respondents, making them unsuitable for analysis. Therefore, data from 120 respondents was eventually used for analysis in this study.

\section{Methods of data collection and analysis}

Primary data was collected from the respondents through a questionnaire complemented by interviews. Though conducted in English, the interviews were interpreted to respondents in their local languages to enable a better understanding when required. Data collected was analyzed with descriptive statistics (frequency, percentages and mean), perception index and the double-hurdle model. The dataset includes socioeconomic characteristics of respondents, awareness and perception about pro-vitamin-A garri, and willingness to pay for pro-vitamin-A garri.

\section{Analytical procedure}

\section{Descriptive statistics}

Descriptive statistics such as percentage, frequency and ranking were used to analyze the socioeconomic characteristics of the respondents' level of awareness and perception of pro-vitamin-A garri.

\section{Awareness index}

A set of questions (with yes or no response choices) were asked as appropriate to calculate the awareness index of pro-vitamin-A garri. Three questions were asked about the respondents' awareness of the availability and health benefits of pro-vitamin-A garri. The estimated index for each of the variables was computed for each respondent as follows:

$$
S_{i j}=\frac{1}{n_{j}} \sum_{k=1}^{n_{j}} A_{k j i}
$$

where:

$S_{j i}$ : estimated awareness index

$A_{k j i}$ : score assigned by an individual in response to the $j$-th question relating to attitude; in the estimation, a score of 1 was assigned if the response to a question is yes and 0 if the response is no; thus, $\mathrm{A}$ is the one or zero response to a specific question. 


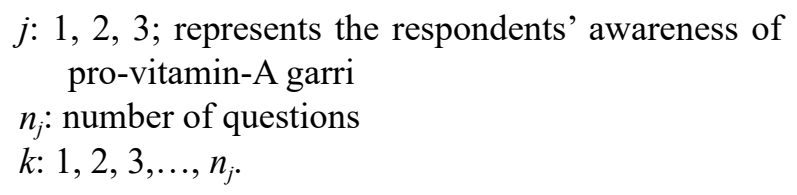

By construction, the value of the index falls between 0 and 1 . For the purpose of descriptive analysis, each index was further transformed such that 1 was assigned to any index value between 0 and $0.399 ; 2$ was assigned to index values between 0.4 and 0.6 ; and 3 was assigned to index values between 0.61 and 1 . Therefore, 1,2 , and 3 mean low, medium and high levels of awareness of pro-vitamin-A garri, respectively.

\section{Perception index}

The perception index was used to examine how provitamin-A garri is perceived by the respondents. Data collected was analyzed with simple descriptive statistics such as a Likert-like 5-point rating scale. In the scale, "Strongly Agree" (SA) has 5 points, "Agree" (A) has 4 points, "Undecided" (U) has 3 points, "Disagree" (D) has 2 points and "Strongly Disagree" has 1 point. Mean Score (MS) is calculated by summation of the product of the rating point $(\mathrm{RP})$ and observation $(\mathrm{O})$ divided by the total number of sampled respondents (£f). Mathematically:

$$
\mathrm{MS}=£\left(\frac{\mathrm{RP} \cdot \mathrm{O}}{£ \mathrm{f}}\right)
$$

\section{Double-hurdle model}

This study adopted the double-hurdle model introduced by Cragg (1971) which involves two equations: first, is the willingness-to-pay decision equation; and second, the amount an individual is willing to pay for pro-vitamin-A garri equation. The Cragg Model presumes that two hurdles have to be crossed by a consumer in order to record a positive willingness to pay (expenditure) for a commodity. The willingness-to-pay decision equation can be stated as follows:

Willingness-to-pay decision (probit) equation:

$$
W_{i}^{*}=Z_{i} \delta+u_{i}
$$

where:

$W$ : latent variable that defines the rule as to whether a respondent would be willing to pay for pro-vitamin-A garri or not;

$Z_{i}$ : vector of exogenous variables; $\delta$ : coefficients associated with the repressors $(Z)$, including the constant term;

$u_{i}$ : error term assumed to be normally distributed (which means a zero mean and a unit variance).

The observed willingness to pay $(W)$ is linked with the latent willingness to pay $W^{*}$ as follows:

$$
W=\left\{\begin{array}{l}
1 \text { if } y^{*}>0 \\
0 \text { otherwise }
\end{array}\right.
$$

The second equation (the amount willing to pay) is stated as:

$$
A^{*}{ }_{i}=X_{i} \beta+\varepsilon_{i}
$$

where:

$A_{i}^{*}$ : latent amount willing to pay for pro-vitaminA garri;

$X_{i}$ : vector of explanatory variables influencing the amount willing to pay (which may be the same as $Z_{i}$ );

$\beta$ : coefficients associated with the repressors $(X)$, including the constant term;

$\varepsilon_{i}$ : error term which is assumed to be normally distributed (with zero mean and constant variance).

The relationship between latent willingness to pay $\left(W^{*}\right)$, the latent amount willing to pay $\left(A^{*}\right)$ and the observed amount willing to pay for pro-vitamin-A $(A)$ is as follows:

$$
A=\left\{\begin{array}{cc}
A^{*} & \text { if } A^{*}>0 \text { and } W=1 \\
0 & \text { otherwise }
\end{array}\right.
$$

The explanatory variables in both equations of the double-hurdle model are as follows:

$X_{1}$ : age of respondents (years);

$X_{2}$ : gender ( 1 if male, 0 otherwise);

$X_{3}$ : marital status ( 1 if single, 0 otherwise);

$X_{4}$ : education (1 if has at least a primary education, 0 otherwise);

$X_{5}$ : household size (number);

$X_{6}$ : household income (in NGN/USD equivalent);

$X_{7}$ : other income sources ( 1 if yes, 0 otherwise);

$X_{8}$ :awareness ( 1 if the respondent is aware of the health benefits of pro-vitamin-A garri via extension services, 0 otherwise);

$X_{9}$ : family and friends ( 1 if the respondent is aware of the health benefits of pro-vitamin-A garri via family and friends, 0 otherwise); 
$X_{10}:$ radio/television ( 1 if the respondent is aware of the health benefits of pro-vitamin-A garri via radio and/or television, 0 otherwise).

The double-hurdle model was estimated using the "craggit option" of the STATA code written by Burke (2009). The standard error robust (OPG) option was selected during estimation. This option is derived from the asymptotic theory, and is robust to some kinds of misspecification and intra-group correlations.

\section{RESULTS AND DISCUSSION}

\section{Socioeconomic characteristics of the respondents}

The socioeconomic characteristics of the respondents are presented in Table 1. Most (48.33\%) respondents were aged between 20 and 30 years while $0.83 \%$ were above 60 years. Only $11.67 \%$ of the respondents were aged between 41 and 50. The mean age of the respondents was 33.4 years and the maximum was ca. 79 years. A total of $58.33 \%$ of the respondents were males while $41.67 \%$ were females. Most (54.17\%) respondents were married while $40.83 \%$ were single. About $88.33 \%$ of the respondents had a formal education, mostly junior/senior secondary education (49.17\%), primary education (14.17\%) and tertiary education (25.0\%), with $11.67 \%$ of the respondents having no formal education. The relatively high level of formal education is expected to induce their willingness to pay for pro-vitamin-A garri. As shown in Table 1, ca. $68.33 \%$ of the respondents had between 4 and 6 members in their households, with an average household size being 5 persons. The results also showed that most respondents had an income between NGN 1000 (USD 2.77) and NGN 20,000 (USD 55.56), with the average monthly income being NGN 43,891.67 (USD 121.92).

\section{Awareness and sources of information of respondents about pro-vitamin-A garri}

Presented in Table 2 are the results indicating the respondents' awareness of pro-vitamin-A garri as regards its health properties and availability. The majority (54.17\%) of respondents indicated they were aware that pro-vitamin-A garri is available in their community for purchase and consumption. Most (66.67\%) of them also declared to be aware that pro-vitamin-A garri is produced from yellow cassava. However, majority (75\%)
Table 1. Distribution of respondents by socioeconomic characteristics

\begin{tabular}{|c|c|c|}
\hline Characteristics & $\begin{array}{c}\text { Frequency } \\
(n=120)\end{array}$ & $\begin{array}{c}\text { Percentage } \\
(\%)\end{array}$ \\
\hline \multicolumn{3}{|l|}{ Age } \\
\hline 20-30 years & 58 & 48.33 \\
\hline $31-40$ years & 39 & 32.5 \\
\hline $41-50$ years & 14 & 11.67 \\
\hline $51-60$ years & 8 & 6.67 \\
\hline$>60$ years & 1 & 0.83 \\
\hline Mean age & 33.4 years & \\
\hline \multicolumn{3}{|l|}{ Gender } \\
\hline male & 70 & 58.33 \\
\hline female & 50 & 41.67 \\
\hline \multicolumn{3}{|l|}{ Marital status } \\
\hline single & 49 & 40.83 \\
\hline married & 65 & 54.17 \\
\hline widowed & 6 & 5.00 \\
\hline \multicolumn{3}{|l|}{ Education level } \\
\hline no formal education & 14 & 11.67 \\
\hline primary education & 17 & 14.17 \\
\hline secondary education & 59 & 49.17 \\
\hline tertiary education & 30 & 25.00 \\
\hline \multicolumn{3}{|c|}{ Household size (persons) } \\
\hline $1-3$ & 13 & 10.83 \\
\hline $4-6$ & 82 & 68.33 \\
\hline $7-9$ & 19 & 15.83 \\
\hline $10-12$ & 5 & 4.17 \\
\hline $13-15$ & 1 & 0.83 \\
\hline Mean & 5 & \\
\hline \multicolumn{3}{|l|}{ Income } \\
\hline 1000-20000 & 55 & 45.83 \\
\hline $20001-40000$ & 26 & 21.67 \\
\hline $40001-60000$ & 17 & 14.17 \\
\hline $60001-80000$ & 8 & 6.67 \\
\hline $80001-100000$ & 3 & \\
\hline Mean income & $\begin{array}{c}\text { NGN } 43,891.67 / \\
\text { USD } 121.92\end{array}$ & \\
\hline
\end{tabular}

Source: field survey data, 2018. 
Table 2. Distribution of respondents by awareness of provitamin-A garri

\begin{tabular}{|c|c|c|}
\hline Awareness-related questions & $\begin{array}{l}\text { Frequency } \\
(n=120)\end{array}$ & $\begin{array}{l}\text { Percentage } \\
(100 \%)\end{array}$ \\
\hline \multicolumn{3}{|l|}{$\begin{array}{l}\text { Are you aware that pro-vitamin- } \\
\text { A garri is available in your } \\
\text { community? }\end{array}$} \\
\hline Yes & 65 & 54.17 \\
\hline No & 55 & 45.83 \\
\hline \multicolumn{3}{|l|}{$\begin{array}{l}\text { Are you aware that pro-vitamin- } \\
\text { A garri is made from yellow } \\
\text { cassava? }\end{array}$} \\
\hline Yes & 80 & 66.67 \\
\hline No & 40 & 33.33 \\
\hline \multicolumn{3}{|c|}{$\begin{array}{l}\text { Are you aware that pro-vitamin- } \\
\text { A garri is more beneficial than white } \\
\text { garri? }\end{array}$} \\
\hline Yes & 30 & 25 \\
\hline No & 90 & 75 \\
\hline \multicolumn{3}{|l|}{ Overall awareness } \\
\hline Low & 63 & 52.5 \\
\hline Medium & - & - \\
\hline High & 57 & 47.5 \\
\hline \multicolumn{3}{|l|}{$\begin{array}{l}\text { Sources of information about } \\
\text { pro-vitamin-A garri }\end{array}$} \\
\hline Agricultural extension agents & 40 & 26.7 \\
\hline Radio & 35 & 23.3 \\
\hline Friends & 26 & 17.3 \\
\hline
\end{tabular}

Source: field survey data, 2018.

of the respondents were not aware of nutrition benefits provided by pro-vitamin-A garri while $25 \%$ of them were aware of it. On the overall level of awareness, the results suggest that $47.5 \%$ of the respondents had high levels of awareness of pro-vitamin-A garri with respect to its availability and nutritional benefits. The level of knowledge is expected to have a positive effect on the willingness to pay.

Note that the consumers received information on pro-vitamin-A garri through agricultural extension agents $(26.7 \%)$, radio $(23.3 \%)$ and friends $(17.3 \%)$.

\section{Perception of the respondents about pro-vitamin-A garri}

Table 3 shows the perception about pro-vitamin-A garri in the study area. The mean score was used in explaining the level of the respondents' perception about provitamin-A garri. According to result, the respondents agreed that pro-vitamin-A garri has a yellow color and a fine look (with the mean score of $\bar{x}=3.61$ ). Also, with the mean score of $\bar{x}=3.53$, the respondents agreed that some additional health benefits can be derived from provitamin-A garri. The respondents agreed to the fact that pro-vitamin-A garri is readily available in the market (with the mean score of $\bar{x}=3.99$ ). Furthermore, the respondents were in agreement to the fact that they prefer to consume pro-vitamin-A garri over other types of garri because of the taste (with the mean score of $\bar{x}=3.52$ ). In addition, the assertion that pro-vitamin-A garri has reduced the consumption of other types of garri intake indicated a mean score of $\bar{x}=3.85$ which shows that consumers agreed with the statement. The assertion that pro-vitamin-A garri will reduce the amount or quantity of other types of garri purchased carries a mean score of $\bar{x}=3.55$. This shows that the consumers were in agreement with this statement. The statement "the consumption of pro-vitamin-A garri will help reduce the amount I usually spend on my family members in the hospital" has the mean score of $\bar{x}=3.55$, indicating an agreement with the statement by the respondents. The result of the respondents' perception about pro-vitamin-A garri is consistent with the findings of De Moura et al., 2015 and Oparinde et al., 2017.

\section{Consumers' willingness to pay an amount for pro-vitamin-A garri}

The consumers' willingness to pay an amount per kilogram of pro-vitamin-A garri is presented in Table 4. The survey found that most $(70.83 \%)$ consumers were willing to pay for pro-vitamin-A garri while $29.17 \%$ were not willing to do so. This indicates that consumers are aware of the importance of pro-vitamin-A garri. The consumers indicated that the product (pro-vitaminA garri) contains nutritive values that could improve their health. The maximum amount the consumers were willing to pay per kilogram of pro-vitamin-A garri was NGN 500 (USD 1.39), the minimum amount was NGN 160 (USD 0.44) and the average amount was NGN 220.08 (USD 0.61). The majority (63.54\%) of consumers were willing to pay between NGN 201 
Ogunmola, O. O., Adekanmbi, A. A. (2020). Awareness, perceptions and willingness to pay for pro vitamin A garri: evidence from Ido local government of Oyo State, Nigeria. J. Agribus. Rural Dev., 1(55), 61-72. http://dx.doi.org/10.17306/J.JARD.2020.01234

Table 3. Distribution of consumer perceptions about pro-vitamin-A garri

\begin{tabular}{|c|c|c|c|c|c|c|c|}
\hline Perceptual statement & $\mathrm{SA}(5)$ & $\mathrm{A}(4)$ & $\mathrm{U}(3)$ & $\mathrm{D}(2)$ & $\mathrm{SD}(1)$ & MS & $\mathrm{R}$ \\
\hline Pro-vitamin-A garri has a yellow color and a fine look & 12 & 24 & 5 & 23 & 56 & 3.61 & A \\
\hline $\begin{array}{l}\text { Some additional health benefits can be derived from pro-vitamin- } \\
\text { A garri }\end{array}$ & 12 & 22 & 12 & 28 & 46 & 3.53 & A \\
\hline $\begin{array}{l}\text { Taste of pro-vitamin-A garri is not as palatable as products from } \\
\text { other garri }\end{array}$ & 45 & - & 6 & 69 & - & 2.84 & $\mathrm{U}$ \\
\hline Pro-vitamin-A garri is costlier than other types of garri & 7 & - & 56 & 28 & 29 & 3.41 & $\mathrm{U}$ \\
\hline Pro-vitamin-A garri is readily available in the market & 3 & 10 & 35 & 19 & 53 & 3.99 & A \\
\hline The health benefit outweighs its cost price & 5 & 2 & 55 & 42 & 16 & 3.29 & $\mathrm{U}$ \\
\hline $\begin{array}{l}\text { Prefer to consume pro-vitamin-A garri over other types of garri } \\
\text { because of the taste }\end{array}$ & 9 & 2 & 41 & 53 & 15 & 3.52 & A \\
\hline $\begin{array}{l}\text { Pro-vitamin-A garri has reduced the consumption of other types } \\
\text { of garri }\end{array}$ & 10 & 3 & 40 & 26 & 41 & 3.85 & A \\
\hline $\begin{array}{l}\text { Pro-vitamin-A garri will reduce the amount/or quantity of other } \\
\text { types of garri purchased }\end{array}$ & 11 & 3 & 32 & 65 & 9 & 3.55 & A \\
\hline $\begin{array}{l}\text { Consumption of pro-vitamin-A garri will help reduce the amount } \\
\text { I usually spend on my family members as hospital }\end{array}$ & 12 & 2 & 28 & 69 & 9 & 3.55 & A \\
\hline
\end{tabular}

Note: SA: strongly agree; A: agree; U: undecided; D: disagree; SD: strongly disagree; R: remarks; total number of respondents (£f)= 120; MS (mean score): summation (£) of rating point $\times$ number of observations $/ £ f$

Source: field survey data, 2018.

Table 4. Consumers' willingness to pay and amounts they are willing to pay for pro-vitamin-A garri

\begin{tabular}{llll}
\hline \multicolumn{1}{c}{ Variable } & \multicolumn{1}{c}{ Description } & Frequency & Percentage \\
\hline $\begin{array}{l}\text { Willing to pay for } \\
\text { pro-vitamin-A garri }\end{array}$ & Yes & 85 & 70.83 \\
& No & 35 & 29.17 \\
$\begin{array}{l}\text { Amount the con- } \\
\text { sumers are willing } \\
\text { to pay per kg }\end{array}$ & 100-200 & 16 & 16.67 \\
& $301-400$ & 61 & 63.54 \\
& $401-500$ & 17 & 17.71 \\
$\begin{array}{l}\text { Minimum amount } \\
\text { per kg willing to pay }\end{array}$ & $\begin{array}{l}\text { NGN 160/kg } 0.44 / \mathrm{kg} \text { ) } \\
\text { (USD }\end{array}$ & 1 & 2.08 \\
$\begin{array}{l}\text { Maximum amount } \\
\text { per kg willing to pay }\end{array}$ & $\begin{array}{l}\text { NGN 500/kg } 1.39 / \mathrm{kg} \text { ) } \\
\text { (USD }\end{array}$ & 1 & 1.04 \\
$\begin{array}{l}\text { Average amount per } \\
\text { kg willing to pay }\end{array}$ & $\begin{array}{l}\text { NGN 220.08/kg } \\
\text { (USD 0.61/kg) }\end{array}$ & \\
\hline
\end{tabular}

Source: field survey data, 2018.
(USD 0.56) and NGN 300 (USD 0.83) per kilogram of pro-vitamin-A garri. In turn, only $2.08 \%$ were willing to pay between NGN 401 (USD 1.11) and NGN 500 (USD 1.39) per kilogram of pro-vitamin-A garri. It can be established that although the respondents are willing to pay for this product, their willingness to pay does not mean the majority of them would pay a higher amount. The consumers who were not willing to pay any amount for the consumption of pro-vitamin-A garri indicated that they lack information or knowledge on its nutritive value.

\section{Determinants of the consumers' willingness to pay and of the amounts they are willing to pay for pro-vitamin-A garri}

Table 5 presents the results of the effects of explanatory variables on the probability that a consumer is willing to pay for pro-vitamin-A garri and the expected amount he/she is willing to pay for a kilogram of pro-vitaminA garri. The estimate of sigma ( $\rho$ ) that maximizes the likelihood function is 48.79 and is different from zero at a 1 percent level of significance which shows that it fits 
significantly (Guerrero, 2007). Such significant sigma ( $\rho$ ) value implies that the residuals of the first and second hurdle are highly correlated. This means that the joint estimation approach is appropriate for the data, and that efficiency is gained by the use of the approach. The log-likelihood function of the model is -544.38; the Wald chi-square value of 33.82 associated with the loglikelihood ratio is statistically significant at 1 percent $(p \leq 0.002)$, implying that all the explanatory variables in the model jointly influence the probability that an average consumer in the study area is willing to pay for and consume pro-vitamin-A garri.

According to the results, consumer income was statistically significant at 10 percent and positively influenced willingness to pay for pro-vitamin-A garri. Intuitively, the increase in the income of consumers will make them more likely to purchase and consume pro-vitamin-A garri. This supports the expectations that consumer income will significantly increase the odds in favor of their decision to pay for pro-vitamin-A garri. This agrees with findings of Ezeh et al. (2012) that as monthly income increases, so does the monthly budget share on garri. Also, the coefficient of other income sources accrued by consumers is positive and statistically significant in determining the probability of their willingness to pay for pro-vitamin-A garri at a 10 percent level of significance. The results suggest that the probability of willingness to pay for pro-vitamin-A garri by the consumers increases with the increase in the amount of other sources of income.

The sources of awareness about the health benefits of pro-vitamin-A garri considered in this study have a positive influence on the probability that a consumer will pay for pro-vitamin-A garri. Extension services and word-of-mouth from friends are those that are statistically significant at a 5 percent level of significance. This implies that the more consumers are aware of provitamin-A garri via these two sources, the more likely they are to be willing to pay for it. Also, these sources have a stronger effect on information dissemination, especially in rural areas and especially in terms of sales promotion and product advertisement. This outcome is in resonance with the findings of De Steura et al., 2016 and Oparinde et al., 2016 that information significantly enhances the willingness to pay for genetically modified foods fortified with vitamins in China.

On the other hand, the second hurdle explains that the coefficient of the consumers' education level (at primary
Table 5. Double-hurdle model for the determinants of consumers' willingness to pay and of the amounts they are willing to pay for pro-vitamin-A garri

\begin{tabular}{|c|c|c|c|}
\hline & Coefficient & $z$-value & $p>|z|$ \\
\hline \multicolumn{4}{|l|}{ Willingness to pay } \\
\hline Age & -0.0222 & -0.96 & 0.335 \\
\hline Gender & -0.1139 & -0.30 & 0.764 \\
\hline Marital status & -0.5866 & -1.00 & 0.315 \\
\hline Education & 0.0461 & 1.19 & 0.234 \\
\hline Household size & -0.0526 & -0.53 & 0.598 \\
\hline Income & $7.14 \mathrm{e}-06^{*}$ & 1.86 & 0.063 \\
\hline Other income sources & $0.7509^{*}$ & 1.83 & 0.067 \\
\hline Awareness (extension services) & $2.0519 * * *$ & 5.38 & 0.000 \\
\hline Awareness (friends) & $2.9092 * * *$ & 7.01 & 0.000 \\
\hline Awareness (radio) & -0.6208 & -1.41 & 0.159 \\
\hline Constant & 0.6204 & 0.59 & 0.554 \\
\hline \multicolumn{4}{|l|}{ Amount willing-to-pay equation } \\
\hline Age & 0.9631 & 1.48 & 0.139 \\
\hline Gender & 3.7405 & 0.35 & 0.725 \\
\hline Marital status & 21.5762 & 1.44 & 0.150 \\
\hline Education & $5.5982 * * *$ & 5.04 & 0.000 \\
\hline Household size & $-7.8853 * *$ & -2.80 & 0.005 \\
\hline Income & -0.0001 & -1.04 & 0.299 \\
\hline Other income sources & -8.7802 & -0.73 & 0.463 \\
\hline Awareness (extension services) & 6.3544 & 0.45 & 0.655 \\
\hline Awareness (friends) & -6.4233 & -0.53 & 0.599 \\
\hline Awareness (radio) & $26.9706^{* *}$ & 2.33 & 0.020 \\
\hline Constant & 253.1494 & 8.18 & 0.000 \\
\hline Sigma $(\rho)$ & 48.7936 & 13.86 & 0.000 \\
\hline Log likelihood & -544.3805 & & \\
\hline Wald chi-square (10) & 33.82 & & \\
\hline$p$-value & 0.0002 & & \\
\hline
\end{tabular}

$* * *, * *$, and $*$ denote statistical significance at $1 \%, 5 \%$ and $10 \%$, respectively.

Source: field survey data, 2018.

level of education) is significant and has a positive influence on willingness to pay for pro-vitamin-A garri at a 1 percent level of significance. This implies that more 
educated consumers will be more willing to pay for provitamin-A garri than less educated consumers. This supports the study by Gustavo et al. (2015) and Bechoff et al. (2018) who found that educated consumers play a crucial role in food consumption. Also, household size was statistically significant at 5 percent and negatively influenced the amount a consumer is willing to pay for one kilogram of pro-vitamin-A garri. This means that as the consumer's household size increases by one person, the amount the consumer is willing to pay for pro-vitaminA garri reduces. This conforms to the a priori expectation and is in line with findings of Jin et al. (2014). The awareness of pro-vitamin-A garri $(p \leq 0.05)$ positively affected the amount a consumer is willing to pay for provitamin A garri. This means that awareness (induced via radio as a source of information dissemination) of health and nutritional benefits derived from consuming provitamin-A garri would substantially enhance the amount a consumer is willing to pay for a kilogram of pro-vitamin-A garri, as also opined by Olatunji et al. (2012).

\section{CONCLUSION AND RECOMMENDATION}

\section{Conclusion}

This study investigated the awareness, perceptions and willingness to pay for pro-vitamin-A garri in Oyo state, Nigeria. A multistage sampling procedure was used to collect data from 150 respondents. The study shows that while ca. $47.5 \%$ of the respondents are aware of the availability of pro-vitamin-A garri, the levels of awareness are low. This is the result of inadequate dissemination of information from the right quarters. However, $67.3 \%$ of the consumers are aware of pro-vitamin-A garri thanks to agricultural extension agents, radio and friends. This shows that pro-vitamin-A garri is well known in the study area. Most of the respondents (70.83\%) were willing to pay for pro-vitamin-A garri but only $1.04 \%$ of the respondents were willing to pay a maximum amount of NGN 500 (USD 1.39). It can be established that although the respondents are willing to pay for this product, their willingness to pay does not mean the majority of them would pay a higher amount. The double-hurdle model was used to determine the factors influencing the respondents' willingness to pay and the amount they are willing to pay for pro-vitamin-A garri in the study area. Income, other income sources and awareness (induced via agricultural extension agents and friends) significantly and positively influenced pro-vitamin-A garri consumers' willingness to pay for it. Similarly, education level and radio-induced awareness significantly and positively influenced the amount they were willing to pay for one kilogram of pro-vitamin-A garri. Conversely, household size of the consumers significantly and negatively influenced the amount they were willing to pay.

\section{Recommendation}

This study recommends that people be well informed and educated on nutritive values and health implications of food commodities, since most of the interviewees were not aware of or did not know the nutritive values and health implications of pro-vitamin-A garri. Also, nutrition education is an important tool in communicating the nutritional and health benefits of bio-fortified crops, and an important factor that affects their acceptability.

\section{SOURCE OF FINANCING}

\section{Self-financed.}

\section{REFERENCES}

Adekunle, C. P., Akerele, D., Adekunle, A. K., Amodemaja, T. S. (2016). Consumers' willingness to pay for organic leafy vegetables in Abeokuta southwest Nigeria: evidence from double bounded dichotomous choice approach. Nig. J. Agric. Food Env., 12(1), 17-23.

Akinpelu, A. O., Amamgbo, L. E. F., Olojede, A. O., Oyekale, A. S. (2011). Health implications of cassava production and consumption. J. Agric. Soc. Res., 11(1), 118-125.

Bechoff, A., Chijioke, U., Westby, A., Tomlins, K. I. (2018). 'Yellow is good for you': Consumer perception and acceptability of fortified and biofortified cassava products. PLoS ONE, 13(9).

Burke, W. J. (2009). Fitting and interpreting Cragg's tobit alternative using Stata. Stata J., 9(4), 584-592.

Cardoso, A. P., Mirione, E., Ernesto, M., Massaza, F., Cliff, J., Haque, M. R., Bradbury, J. H. (2005). Processing of cassava roots to remove cyanogens. J. Food Comp. Anal., 18(5), 451-460.

Cragg, J. G. (1971). Some statistical models for limited dependent variables with application to the demand for durable goods. Econometrica (pre-1986), 39(5), 829.

Danso-Abbeam, G., Setsoafia, E. D., Ansah, I. G. K. (2014). Modelling farmers investment in agrochemicals: the experience of smallholder cocoa farmers in Ghana. Res. Appl. Econ., 6(4), 1-15. 
De Moura, F. F., Moursi, M., Abdelrahman Lubowa, B. H., Boy, E., Oguntona, B., Sanusi, R. A., and Maziya-Dixon, B. (2015). Cassava intake and vitamin A status among women and preschool children in Akwa-Ibom, Nigeria. PLoS One, 10(6).

Denton, O., Ogunkunle, A. (2014). Land use change analysis in a derived Savannah zone of south western Nigeria and challenges for agricultural land. J. Biol. Agric. Health., 4(18), 68-75.

De Steura, H., Blancquaertb, D., Strobbeb, S., Fengc, S., Buyssea, J., Stoved, C., Lambertd, W., Van Der Straetenb D., Gellyncka, X. (2016). Consumer acceptance and willingness-to-pay for genetically modified foods with enhanced vitamin levels. In: Genetically modified organisms in food: production, safety, regulation and public health (pp. 195-206). Elsevier Academic Press.

Egesi, C., Mbanaso, E., Ogbe, F., Okogbenin, E., Fregene, M. (2006). Development of cassava varieties with high value root quality through induced mutations and marker-aided breeding. NRCRI, Umudike Annual Report (pp. 2-6).

Ender, G., Cooper, P., McGuire, J., Michaels, G., Welch, R. (2014). Case Study: Vitamin A-fortified Maize and Cassava in Nigeria. Unpublished report submitted to HarvestPlus.

Ezeh, C. I., Anyiro, C. O., Obioma, N. Q., Maduagwu, O. C. (2012). Demand Structure and the Consumption of Garri in Owerri North Local Government Area of Imo State, Nigeria. Int. J. Agric. Forest., 2(6), 273-278.

FAO (2013). Save and Grow: Cassava: a guide to sustainable production intensification. Rome: Food and Agriculture Organization of the United Nations.

FAO, IFAD, World Food Programme (2015). The State of Food insecurity in the World. Rome: Food and Agriculture Organization of the United Nations.

Gabre-Madhin, E., Barret, C. B., Dorosh, P. (2003). Technological change and price effects in agriculture: Conceptual and comparative perspectives. MTID Discussion Paper No. 62, IFPRI. Washington, DC, USA.

Government of Oyo State (2018). Official website of Oyo State Government: Our history. Retrieved April 20 $0^{\text {th }}$ 2018 from: http://www.oyostate.gov.ng/about-oyo-state/ our-history/

Green, A. S., Fascetti, A. J. (2016). Meeting the vitamin A requirement: the efficacy and importance of $\beta$-carotene in animal species. Sci. World J. Retrieved from: https:// www.ncbi.nlm.nih.gov/pmc/articles/PMC5090096/

Greiner, T. (2017). Combatting Vitamin A deficiency: overcoming obstacles to optimize the food-based approach. World Nutr., 8(2), 151-206.

Guerrero, V. (2007). Una prueba de bondad de ajuste para la distribución logística. Tesis de Maestría. Colegio de
Postgraduados. Postgrado de Socioeconomía, Estadística e Informática Economía. Montecillo, Texcoco, Estado de México, México.

Ilona, P., Bouis, H. E., Palenberg, M., Moursi, M., Oparinde, A. (2017). Vitamin A Cassava in Nigeria: Crop Development and Delivery. Afr. J. Food Agric. Nutr. Dev., 17(2), 12000-12025.

Jin, J., Wailes, E. J., Dixon, B. I., Nayga, R. M., Zheng, Z. (2014). Consumer acceptance and willingness to pay for genetically modified rice in China. In: Agricultural and Applied Economics Association's 2014 AAEA Annual Meeting, Minneapolis, MN July 27-29.

Katona, P., Katona-Apte, J. (2008). The interaction between nutrition and infection. Clin. Inf. Dis., 46(10), 1582-1588.

Kennedy, G., Nantel, G., Shetty, P. (2003). The scourge of "hidden hunger" global dimension of micronutrient deficiencies. J. Food Nutr. Agric., 32, 8-16.

Khan, M., Damalas, C. A. (2015). Farmers' willingness to pay for less health risks by pesticide use: A case study from the cotton belt of Punjab, Pakistan. Sci. Total Env., 530, 297-303.

Kuku-Shittu, O., Mathiassen, A., Wadhwa, A., Myles, L., Ajibola, A. (2013). Comprehensive food security and vulnerability analysis: Nigeria (No. 1275). International Food Policy Research Institute (IFPRI).

Kwadzo, G. T., Kuwornu, J. K., Amadu, I. S. (2013). Food Crop Farmers' Willingness to Participate in Market-Based Crop Insurance Scheme: Evidence from Ghana. Res. Appl. Econ., 5(1), 1-21.

Liu, Z., Zhang, W. (2011). Which factors affect farmers' willingness for soil testing technology adoption: A case study of Tai Lake Watershed, China.

Maziya-Dixon, B., Onyezili, F., Oguntona, E. B., Harris, E., Sanusi, R., Nokoe, S., Manyong, V., Almustafa, D., Akinyele, I. (2006). Nigeria food consumption and nutrition survey 2001-2003 interviewers manual.

Meenakshi, J. V., Johnson, N., Manyong, V., DeGroote, H., Javelosa, J., Yanggen, D., Naher, F. (2010). How costeffective is bio-fortification in combating micronutrient malnutrition? An ex ante assessment. World Dev., 38(1), 64-75.

Musah, A. B. (2013) Market participation of smallholder farmers in the Upper West Region of Ghana. (Unpublished Thesis). Department of Agricultural Economics and Agribusiness, University of Ghana.

Nakanyike, S. (2014). Farmers' willingness to pay for virusfree sweet potato vines in Central Uganda: a case of Mpigi and Wakiso Districts. Unpublished Masters Thesis, Makarere University, Uganda.

Norris, P. E., Batie, S. S. (1987). Virginia farmers' soil conservation decisions: An application of Tobit analysis. J. Agric. Appl. Econ., 19(1), 79-90. 
NPC (National Population Commission). (2006). Population and Housing Census. Population Local Government Area and Sex. Retrieved from: http://population.gov.ng/ coreactivities/surveys/dataset/2006-phc-priority-tables/

Ogunmoyela, O. A., Adekoyeni, O., Aminu, F., Umunna, L. O. (2013). A critical evaluation of survey results of vitamin A and Fe levels in the mandatory fortified food vehicles and some selected processed foods in Nigeria. Nig. Food J., 31(2), 52-62.

Okoffo, E. D., Denkyirah, E. K., Adu, D. T., Fosu-Mensah, B. Y. (2016). A double-hurdle model estimation of cocoa farmers' willingness to pay for crop insurance in Ghana. SpringerPlus, 5(1), 873.

Oparinde, A., Abdoulaye, T., Mignouna, D. B., Bamire, A. S. (2017). Will farmers intend to cultivate Provitamin A genetically modified (GM) cassava in Nigeria? Evidence from a k-means segmentation analysis of beliefs and attitudes. PLoS ONE 12(7), e0179427.

Oparinde, A., Banerji, A., Birol, E., Ilona, P. (2016). Information and consumer willingness to pay for biofortified yellow cassava: evidence from experimental auctions in Nigeria. Agric. Econ., 47(2), 215-233.

Oyawole, F. P., Ajayi, O. P., Aminu, R. O., Akerele, D. (2016). Willingness to pay for improved solid waste management services in an urbanizing area in South-East Nigeria. Ethiop. J. Env. Stud. Manag., 9(6), 793-803.

Parkes, E. Y., Fregene, M., Dixon, A., Boakye-Peprah, B., Labuschagne, M. T. (2013). Combining ability of cassava genotypes for cassava mosaic disease and cassava bacterial blight, yield and its related components in two ecological zones in Ghana. Euphytica, 194(1), 13-24.

Saltzman, A., Birol, E., Bouis, H. E., Boy, E., De Moura, F. F., Islam, Y. Pfeiffer, W. H. (2014). Biofortification: Progress towards a more nourishing future. Bread and Brain, Education and Poverty. Pontifical Academy of Sciences, Vatican City. Scripta varia 125. Retrieved from: www.pas. $\mathrm{va} /$ content/dam/accademia/pdf/sv125/sv125-bouis.pdf

Sanni, L. O., Adebowale, A. A., Awoyale, W., Fetuga, G. O. (2008). Quality of gari (roasted cassava mash) in Lagos State, Nigeria. Nig. Food J., 26(2), 125-134.

Sanusi, R. A., Akinyele, I. O. (2006). Nigeria: Per Capita Consumption of Vitamin A-Fortified Wheat/Maize Flour, Sugar and Vegetable Oil. Unpublished report submitted to UNICEF, August 2006.

Sarris, A., Karfakis, P., Christiaensen, L. (2006). Producer demand and welfare benefits of minimum price insurance for export crops in Tanzania. FAO commodity and trade policy research working paper No. 18.

Sindi, J. K. (2008). Kenya's domestic horticulture subsector: what drives commercialization decisions by rural house- holds? A Published MSc. Thesis, Department of Agricultural, Food, and Resource Economics, Michigan State University.

Talsma, E. F., Brouwer, I. D., Verhoef, H., Mbera, G. N., Mwangi, A. M., Demir, A. Y., Melse-Boonstra, A. (2016). Biofortified yellow cassava and vitamin A status of Kenyan children: a randomized controlled trial. Am. J. Clin. Nutr., 103(1), 258-267.

Taneja, G., Pal, B. D., Joshi, P. K., Aggarwal, P. K., Tyagi, N. K. (2014). Farmers preferences for climate-smart agriculture: an assessment in the Indo-Gangetic Plain (vol. 1337). Intl Food Policy Res Inst.

Tanumihardjo, S. A., Russell, R. M., Stephensen, C. B., Gannon, B. M., Craft, N. E., Haskell, M. J., Lietz, G., Schulze, K., Raiten, D. J. (2016). Biomarkers of Nutrition for Development (BOND) - vitamin A review. J. Nutr., 146(9), 1816S-1848S.

Truman, P. P., Daphnes, S. T., Lateef, S., Malachy, O. A. (2004). The Global Cassava Development Strategy, A Cassava Industrial Revolution in Nigeria. The Potential for a New Industrial Crop". International Fund for Agricultural Development Food and Agriculture Organization of the United Nations P. 9, 16.

Uchendu, F. N., Atinmo, T., Oyewole, O. (2012). Stability of vitamin a in selected nigerian bread made from commercial fortified wheat flour. Int. J. Appl. Sci. Tech., 2(3), 1-6.

Ulimwengu, J., Sanyal, P. (2011) Joint estimation of farmers' stated willingness to pay for agricultural services. IFPRI Discussion Paper 01070.

Vandeveer, M. L., Loehman, E. T. (1994). Farmer response to modified crop insurance: a case study of corn in Indiana. Am. J. Agric. Econ., 76(1), 128-140.

Weather2 (2017). Local Weather Forecast: Abeokuta Weather Chat. RetrievedApril 30 2018 from: http://www.myweather2.com/activity/weathermaps.aspx?mapid=8\&id=70992

West, K. (2002). Erratum: Extent of vitamin A deficiency among preschool children and women of reproductive age. J. Nutr., 132(11), 2857s-2866s.

West, K. P., Darnton-Hill, I. (2008). Vitamin A deficiency. In: R. D. Semba, M. W. Bloem (Eds.), Nutrition and Health in Developing Countries ( $2^{\text {nd }}$ ed., pp. $\left.377-433\right)$. Totowa, NJ: Humana Press.

Wodjao, T. B. (2008). A double-hurdle model of computer and internet use in American households. Michigan: Department of Economics, Western Michigan University.

Yu, X., Abler, D. (2010). Incorporating zero and missing responses into CVM with open-ended bidding: willingness to pay for blue skies in Beijing. Env. Dev. Econ., 15(5), 535-556. 